INTERNATIONAL JOURNAL OF RESEARCHES IN BIOSCIENCES, AGRICULTURE AND TECHNOLOGY (c) VISHWASHANTI MULTIPURPOSE SOCIETY (Global Peace Multipurpose Society) R. No. MH-659/13(N) www.ijrbat.in

\title{
SURVEY ON TREE DIVERSITY OF JM PATEL COLLEGE CAMPUS, BHANDARA,(M.S).
}

\author{
Padmavathi S. Rao and Shweta P. Udapure \\ Dept. of Botany, J.M.Patel College, Bhandara(M.S). \\ padmavathirao6@gmail.com
}

\begin{abstract}
:
The present study deals with the status, distribution, identification, diversity, and curative values of medicinal Trees in J.M.Patel College campus, Bhandara. The college is one of the leading and premier institutes with ' $\mathrm{A}$ ' grade accreditation and status of College with Potential for Excellence by UGC. It is also recognized as centre for 'Higher Learning \& Research' by RTM Nagpur University. The biorich campus sprawling over 21,481 sq. m. with a latitude $21.1614397 \mathrm{~N}$ and longitude $79.65108 \mathrm{E}$ and consists of some old trees along with shrubs, herbs, palms, climbers and few exotic flora. In view of recent demand on medicinal plants, the entire lush-green campus was surveyed to collect the tree diversity data. Interestingly more than 200 trees were recorded, among these, 54 tree species were identified by using relevant scientific literature and subsequently the data was evaluated in the present paper.
\end{abstract}

Keywords: Diversity, Flora, palm, shrub, Tree.

\section{INTRODUCTION:}

Biodiversity provides a variety of environmental services from its species that are essential at the global, regional and local level. Unfortunately man is only the contributor to the rapid global destruction of biodiversity. Maintaining of carbon dioxide and oxygen percentage, water cycle and controlling air, water and soil pollution are some unique services of plants. Therefore, preservation of biological resources is essential for the well being and the long term survival of mankind. Therefore, there is a lot of demand for database of plants all over the world especially from biodiversity rich countries as there are a number of economically and medicinally important plants available, which are untapped till now.

The eco friendly, biorich campus of JMPC is covered with rich flora of trees with a thick, green upper canopy. The biotic survey of the campus was carried out in different localities of the campus. There are many socio-economical valuable trees grown in the campus. Most of the trees are naturally grown and some of the trees, shrubs and palms are planted obviously to control pollution and for the beautification of the campus.
In view of this, J.M.Patel College Campus has been selected as an experimental area for studying the tree diversity.

\section{METHOD AND MATERIAL:}

The tree flora in the campus is critically surveyed in different localities of the campus. Identification of flora was done with the help of literature available in College library.

\section{RESULTS AND DISCUSSION}

The entire bio rich campus was surveyed to collect information of tree flora. Interestingly more than 54 tree species of total trees approximately 200 were identified using relevant scientific literature and subsequently the medicinal values of each tree was also reviewed.

College management is regularly taking traditional care (sprinkler and drip irrigation) for the conservation of these trees. On the other hand, advanced equipment are using for trimming of trees which gives extra beautification and healthy atmosphere to the campus.

Campus flora consists of 95 trees, 20 shrubs, 90 palms, belongs to 21 families of angiosperms. Complete information of every tree was given in the form of Q R code. Most of the trees are old and tall 
with thick, green canopy which is suitable for the growth of the lower group plants like lichens, bryophytes and different types of mushrooms on the bark of the trees in late rainy season and also provides shelter to birds and insects.

The collected data was enumerated in alphabetical sequence, with scientific, local name and medicinal values. The works of Ugemuge (1986), Auti et.al (2004), Bondya\& Sharma (2005), Shrivastava and Jain (2006), Phukan (2006), Rao et.al (2017) were referred for taxonomic identification.

\section{CONCLUSION:}

Generally every educational institute right from primary school to university maintained and preserves biodata of staff and students of all the years. Likewise we should preserve the list of flora and fauna found in institute campus and upload in the institute website. It has become obvious that the conservation of biological resource is essential for the well being and the long term survival of mankind.

\section{ACKNOWLEDGMENTS:}

We are thankful to our Principal Dr.VikasDhomne for encouraging and providing library facilities.

REFERANCE :
Auti, B.K., Pingle S.D. and Aher R.K. (2004): Survey of weeds and their medicinal value from ShrirampurTahsil (Ahmadnagar Dt.). Ad. Plant Sci. 17(II) Pp. 395-401.

Bondya, S.L. and Sharma H.P (2005): Impact of biotic interference to the Medicinal plants of Bhavagora , Jharkhand. Ad.Plant Sci. 18(I) Pp.143-146.

NeerajShrivastava and Shuchitrajain. (2006): Floristic diversity in Haroti of Rajasthan. Ad.Plant Sci. 19 (I) Pp.209-213.

Phukan, S.N. (2006): Ethnobotanical values of some weed flora of kitchen gardens in Lakhimpur,Assam.Ad.Plant Sci. 19 (I)Pp. 193195.

Rao, P.S, Yadav, A.M and Shah, R.C.(2017): A survey on biodiversity of J.M Patel College Campus, Bhandara, Maharashtra. ESSENCE- Int. J. for Env.Rehabilitation and Conservation.Vol: VIII (2) Pp. 29-33.

Book:

ErachBharucha. (2006): Text book of Environmental Studies,Universities Press India Private Limited,3-5-819,Hydergudu,Hyderabad.

Ugamuge, N.R. (1986): Flora of Nagpur District, Shree Prakashan Publications, Nagpur. 
Table 1: List of Trees/Shrubs in JMPC campus

\begin{tabular}{|c|c|c|c|c|}
\hline S.No & Botanical Name & Common Name & Medicinal Value & Number of trees \\
\hline 1. & $\begin{array}{l}\text { Acacia auriculiformis A.Cunn. ex } \\
\text { Benth. }\end{array}$ & Australian babul & Malaria and allergy. & 01 \\
\hline 2. & $\begin{array}{l}\text { Acacia catechu } \\
\text { (L.f) Willd. }\end{array}$ & Khair & $\begin{array}{l}\text { Astringent, diarrhea and } \\
\text { Leprosy. }\end{array}$ & 01 \\
\hline 3 & Achras sapota L. & Chikoo & $\begin{array}{l}\text { Anti-inflamatory, helps in } \\
\text { digestion. }\end{array}$ & 01 \\
\hline 4 & Aeglemarmolos(L.) A.Lyons. & Bel & $\begin{array}{l}\text { Dispepsia, dysentery and } \\
\text { diabetes. }\end{array}$ & 02 \\
\hline 5 & Albizialebbeck (L.) Willd. & Shirish & Seed oil for curing Leprosy. & 01 \\
\hline 6 & Annona reticulate $\mathrm{L}$. & Ramphal & diarrhea and dysentery. & 01 \\
\hline 7 & Annona squamosaL. & Sitaphal & $\begin{array}{l}\text { Dipression disorders and } \\
\text { Anaemia. }\end{array}$ & 01 \\
\hline 8 & Areca vestiaria Giseke. & Crown palm & Male contraceptive. & 21 \\
\hline 9. & AzadirachtaindicaA.Juss. & Kadu Neem & $\begin{array}{l}\text { Skin diseases, eczema and } \\
\text { Malarial fever. }\end{array}$ & 05 \\
\hline 10. & BombaxceibaL. & $\begin{array}{l}\text { Red silk cotton } \\
\text { tree }\end{array}$ & $\begin{array}{l}\text { Chronic inflammation, } \\
\text { Dysentery \& haemoptysis. }\end{array}$ & 01 \\
\hline 11. & $\begin{array}{l}\text { Callistemnon lanceolatus } \\
\text { (Curtis)Dum.Cours. }\end{array}$ & Bottle-brush & $\begin{array}{l}\text { Skin diseases, } \\
\text { tuberculous glands\& } \\
\text { burning sensation. }\end{array}$ & 01 \\
\hline 12. & Cassia fistula $\mathrm{L}$. & Bahava & $\begin{array}{l}\text { Diarrhoea,dysentery and } \\
\text { anticough. }\end{array}$ & 01 \\
\hline 13. & $\begin{array}{l}\text { Cassia siamea(Lam.)Irwin et } \\
\text { Barneby. }\end{array}$ & Semal & $\begin{array}{l}\text { Headache, diabetes and } \\
\text { bleeding. }\end{array}$ & 02 \\
\hline 14. & Ceiba pentandra (L.) Gaertn. & Kapok tree & $\begin{array}{l}\text { Asthma, bleeding and } \\
\text { fever. }\end{array}$ & 01 \\
\hline 15. & Chommi feramukul Jacq. & Guggul & Controls cholesterol & 01 \\
\hline 16. & Cocos nucifera L. & Nariyal & $\begin{array}{l}\text { Rheumatism, backpains } \\
\text { and stomach-ache. }\end{array}$ & 04 \\
\hline 17. & Coffea Arabica L. & Coffee & $\begin{array}{l}\text { Fever, asthma, whooping } \\
\text { and cough. }\end{array}$ & 01 \\
\hline 18. & Cordia dichotoma $\mathrm{L}$. & Bhokar & $\begin{array}{l}\text { Lung disease, cough and } \\
\text { urethra. }\end{array}$ & 02 \\
\hline 19. & Dalbergia latifolia Roxb. & Pahari Sheesham & $\begin{array}{l}\text { Diarrhea, dysentery, and } \\
\text { diuretic. }\end{array}$ & 01 \\
\hline 20 & Dalbergia sissoo Roxb. & Sheesham & $\begin{array}{l}\text { diarrhea, indigestion, and } \\
\text { leprosy. }\end{array}$ & 02 \\
\hline 21. & Delonix regia (Boj. Ex Hook) Raf. & Gulmohar & $\begin{array}{l}\text { Anti-diabetic, } \\
\text { anti-inflammatory, }\end{array}$ & 04 \\
\hline 22. & Emblica officinalis L. & Awla & $\begin{array}{l}\text { Inflammatory, antiulcer, and } \\
\text { anticancer. }\end{array}$ & 01 \\
\hline 23. & Eucalyptus globules Labill. & Nilgiri & Asthma, cough and plague. & 01 \\
\hline 24. & Ficus bengalensis $\mathrm{L}$. & Vad & $\begin{array}{l}\text { Diarrhoea,dysentery and } \\
\text { Diabetes. }\end{array}$ & 01 \\
\hline
\end{tabular}




\begin{tabular}{|c|c|c|c|c|}
\hline 25. & $\begin{array}{l}\text { Ficus benjamina var. comosa } \\
\text { (Roxb.) Kurz }\end{array}$ & Weeping fig & $\begin{array}{l}\text { Liver diseases, rheumatic } \\
\text { headaches and wounds. }\end{array}$ & 10 \\
\hline 26. & Ficus carica L. & Anjeer & $\begin{array}{l}\text { Gastrointestinal and } \\
\text { respiratory problems. }\end{array}$ & 03 \\
\hline 27. & Ficus glomerata & Gular & $\begin{array}{l}\text { Diabetes, asthma and } \\
\text { ulcer. }\end{array}$ & 01 \\
\hline 28. & Ficus religiosa (L.) Gasp. & Peepal & $\begin{array}{l}\text { Wounds, skin diseases and } \\
\text { Asthema. }\end{array}$ & 01 \\
\hline 29. & $\begin{array}{l}\text { Gliricidia sepium (Jacq.) Kunth ex } \\
\text { Walp. }\end{array}$ & Giripushpa & Digestive problems. & 01 \\
\hline 30. & Gmelina arborea Roxb. & Shivan & $\begin{array}{l}\text { Abdominal pains, leprosy } \\
\text { and Ulcer. }\end{array}$ & 01 \\
\hline 31. & Kigelia pinnata DC. & Jar Phanas & Acne, leprosy and syphilis. & 01 \\
\hline 32. & Lagerstroemia speciosa(L.)Pers. & Dhayti & $\begin{array}{l}\text { Diabetes, weight loss and } \\
\text { malerial fever. }\end{array}$ & 01 \\
\hline 33. & Madhuca longifolia(J.K)J.F. Mac. & Mahwa & $\begin{array}{l}\text { Diabetes,rheumatism and } \\
\text { dental-related problem. }\end{array}$ & 01 \\
\hline 34. & Mangifera indica $\mathrm{L}$. & Aam & $\begin{array}{l}\text { Asthama, wounds and } \\
\text { ulcers. }\end{array}$ & 04 \\
\hline 35. & Mimusops elengi L. & Bakul & $\begin{array}{l}\text { Diarhoea, dysentery and } \\
\text { ulcer. }\end{array}$ & 25 \\
\hline 36. & Morus alba L. & Mulburry & Injury,cough and oedema. & 01 \\
\hline 37. & Moringa oleifera Lam. & Mungana & $\begin{array}{l}\text { Paralysis, inflammation } \\
\text { and Amenorrhoe. }\end{array}$ & 01 \\
\hline 38. & Murraya paniculata (L.)Jack. & Kamini & $\begin{array}{l}\text { Anti-diarrhoeal, anti- } \\
\text { inflammatory. }\end{array}$ & 01 \\
\hline 39. & Murraya koenigii(L.) Sprengel. & Meetaneem & $\begin{array}{l}\text { Anti-diabetic,blood purifier } \\
\text { and antifungal. }\end{array}$ & 03 \\
\hline 40. & Nyctanthus arbortristis $\mathrm{L}$. & Parijatak & $\begin{array}{l}\text { Sciatica, arthritis and } \\
\text { chronic. }\end{array}$ & 01 \\
\hline 41. & Parkiabi glandulosa R.Br. & Chenduphal & $\begin{array}{l}\text { Hypertension, anti- } \\
\text { malarial and antibacterial. }\end{array}$ & 01 \\
\hline 42. & Phoenix sylvestris L. & Date-palm & $\begin{array}{l}\text { Fever, vomiting and } \\
\text { abdominal complaints }\end{array}$ & 01 \\
\hline 43. & Pithacelobium dulce Mart. & Jungliimli & $\begin{array}{l}\text { Chronic, diarrhea and } \\
\text { dysentery. }\end{array}$ & 02 \\
\hline 44. & Plumeria rubraL. & Champa & $\begin{array}{l}\text { Purgative, cardiotonic and } \\
\text { diuretic. }\end{array}$ & 01 \\
\hline 45. & Polyalthea longifoliaSonn. & Ashoka & $\begin{array}{l}\text { Antipyretic, diarrhea } \\
\text { coughing. }\end{array}$ & 03 \\
\hline 46. & Pongamiapinnata(L.) Pierre & Karanja & $\begin{array}{l}\text { Cleaning teeth, ulcer and } \\
\text { skin diseases. }\end{array}$ & 05 \\
\hline 47. & Roystonearegia(Kunth)O.F.Cook & Royal plam & $\begin{array}{l}\text { Diabetes \& prostate } \\
\text { hyperplasia. }\end{array}$ & 70 \\
\hline 48. & Saracaindica L. & Sitaasoka & $\begin{array}{l}\text { Bleeding, cardiac disorder } \\
\text { and abdominal tumour. }\end{array}$ & 01 \\
\hline 49. & Streblusasper Lour. & Kalyos & Filariasis, leprosy, cancer. & 04 \\
\hline 50. & Syzygium cumini (L.) Skeels & Jamun & Diabetes, diarrhea and & 10 \\
\hline
\end{tabular}




\begin{tabular}{|c|l|l|l|c|}
\hline & & & asthma. & \\
\hline 51. & Tamirindus indica L. & Imli & Jaundice, scabies, ulcers. & 05 \\
\hline 52. & Terminalia catappa L. & Jungli Badam & $\begin{array}{l}\text { Expectorant, liver disease } \\
\text { and Anti HIV. }\end{array}$ & 04 \\
\hline 53. & Tectona grandis L. & Sagwan & $\begin{array}{l}\text { Piles, leucoderma and } \\
\text { dysentery. }\end{array}$ & 04 \\
\hline 54. & Vitex negundo L. & Samhalu & Antiseptic, sprains, cough. & 01 \\
\hline
\end{tabular}

